\title{
Establishing an applied training session in metrology at an agricultural engineering school (CIRAD, Montpellier, France)
}

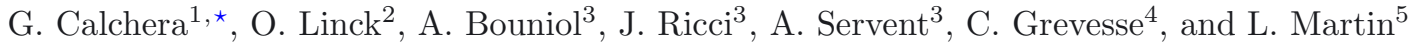 \\ ${ }^{1}$ CIRAD, Head of the metrology platform, Office of the Director General in charge of Resources and Organization, Montpellier, \\ France \\ 2 SupAgro, Lecturer/Researcher, Montpellier, France \\ 3 CIRAD, UMR Qualisud, Montpellier, France \\ 4 CIRAD, Coordinator for Research Infrastructures, Office of the Director General in charge of Research and Strategy, \\ Montpellier, France \\ ${ }^{5}$ CIRAD, UPR BioWooEB, Montpellier, France
}

Received: 20 February 2014 / Accepted: 7 July 2014

\begin{abstract}
As part of its training activities, SupAgro - Institut des Régions Chaudes (IRC), an agricultural engineering school in Montpellier, has introduced an applied training session in metrology for its students. This was undertaken by the CIRAD metrology platform in partnership with the agrifood technology platform of the Qualisud Joint Research Unit. The session comprises two hour workshops during which students can apply the basic notions required for metrological monitoring of the quantities "temperature" and "weight". To that end, standard weights, a temperature calibration device comprising a thermostatically controlled calibration oil bath (uncertainty at $k=2$ of $0.14{ }^{\circ} \mathrm{C}$ ) and a standard temperature probe with an accuracy of $\pm 0.01{ }^{\circ} \mathrm{C}$ were made available to the technology platform by the CIRAD metrology platform. During practical work, these COFRAC calibrated instruments are used to check balances and, in particular, make students aware of the importance of parameters that might influence the temperature measurement of a thermostatically controlled bath (homogeneity, resolution and accuracy of the thermometers, measurement repeatability, etc.). To that end, the Qualisud team specifically adapted a water bath so as to be able to position several temperature probes at different places in the bath. Students have to acquire an approach that needs to take into account a particular measuring context. The teaching scenario of the training session is structured around these metrological checks proposed directly to the students. The training session takes place each year with 2nd year students on the SAADS 2/IAAS course "Sustainable Agriculture and Agrifood Systems in the South" at SupAgro in Montpellier.
\end{abstract}

Keywords: Metrology, uncertainty, traceability, reliability, research, training

\section{Introduction}

CIRAD, a French agricultural research centre for international development, is a French public industrial and commercial establishment placed under the dual authority of the Ministry of Higher Education and Research, and the Ministry of Foreign and European Affairs. Along with countries in the South, CIRAD takes up the international challenges of agriculture and development.

CIRAD's activities cover the life sciences, social sciences and engineering sciences applied to agriculture, food and the environment. In order to guarantee the reliability of research results, CIRAD has deployed a metrology platform.

CIRAD is very actively involved in training French and overseas students and young researchers. Indeed, it

* Correspondence: gilles.calchera@cirad.fr is a major partner for several graduate schools in the field of agronomy and is a founding member of Agreenium (www.agreenium.org). It was in connection with training activities at SupAgro - Institut des régions chaudes (IRC), an agricultural engineering school in Montpellier, that the metrology platform, in partnership with the agrifood technology platform of the Qualisud Joint Research Unit, set up an applied training session in metrology intended for students. By way of two hour workshops, students could apply the basic notions associated with the metrological monitoring of the quantities "temperature" and "weight".

In the first workshop, students carried out several tests on a precision balance: accuracy, repeatability, off-centre load and linearity. The purpose of the second workshop was to have students estimate the uncertainty associated with the temperature value of the water in a water bath. 


\section{Practical work specific to the metrological verification of a precision balance}

The purpose of this workshop was to place students in a situation where they had to deal with the degree of reliability of values provided by a precision balance, a measuring instrument that is very widely used in laboratories.

The capacity of the balance used was $110 \mathrm{~g}$, with a resolution of $1 \mathrm{mg}$ and a verification scale [1] of $10 \mathrm{~g}$ $(e=10 \mathrm{~d})$.

The students were asked the following question:

What is the estimation of doubt surrounding the measurement when weighing on this balance?

The students were provided with standard weights for the purpose (Fig. 1).

The nominal values and accuracy classes for these standard weights were as follows:

- $100 \mathrm{~g}$ in F1 ( $\pm 0.50 \mathrm{mg})$;

- $50 \mathrm{~g}$ in $\mathrm{F} 1( \pm 0.30 \mathrm{mg})$;

$-1 \mathrm{~g}$ in F1 ( $\pm 0.10 \mathrm{mg})$.

At the start of the exercise, the teaching scenario was as follows: the students shared their points of view regarding the situation and an instructor guided them to choose the right procedure.

Initially, consideration was given to the general condition of the balance (cleanness, spirit level, tare, etc.). The students were then led to ask themselves certain questions, such as:

- has the balance been switched on for a few minutes?

- do the COFRAC calibrated standard weights correspond to the operating range of the balance in question?

- is the balance in the right environmental conditions: no draughts, vibration, heat source, stability of the base, etc.?

Particular attention was paid to the standard weights which were handled with care using "precision" gloves.

The students were then asked to carry out a methodological verification using the weights provided.

This verification comprised four tests:

- accuracy;

- repeatability;

- off-centre load;

- linearity.

The instructor explained the good practices expected during the different tests. For example, the accuracy test consisted in delicately placing the standard weight in the middle of the balance platform and repeating the operation several times, without establishing the tare between the different measurements. An accuracy error could thus be estimated. This was the mean of the values read minus the conventionally true value of the standard weight used. A standard error of repeatbility could also be estimated.

The off-centre load test was carried out by positioning the $50 \mathrm{~g}$ standard weight in the middle of the platform. The balance was then tared. The test consisted in moving

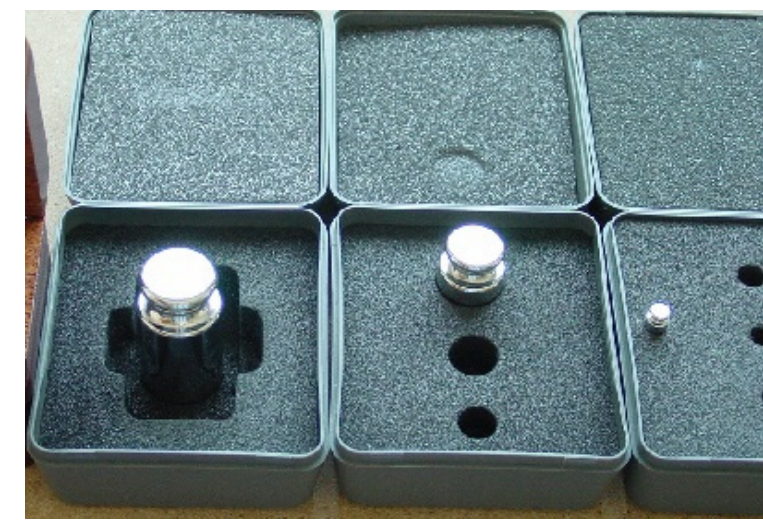

Fig. 1. Chosen standard weights.

the standard weight to the four corners of the platform to check that the balance display always indicated "0.000 g". An off-centre load error could thus be determined.

Additionally, a linearity test may be proposed. This involves carrying out a series of increasing, then decreasing measurements using the standard weights, without returning to zero between measurements.

These two hours of practical work enabled the students to become aware of the sources of uncertainty associateed with the weighing operation and determine a conformity zone for using the balance [2].

Lastly, the capability of the standard masses in relation to the accuracy class of the balance to be checked was calculated [3] to make the students aware of the importance of checking the metrological coherence of their equipment.

\section{Practical work specific to the metrological verification of a water bath}

The purpose of this second workshop was to have the students consider the different influence quantities involved in measuring the temperature of a water bath containing water at $37^{\circ} \mathrm{C}$ (water bath heat setting).

The following equipment was provided:

- $25(\mathrm{~W}) \times 60(\mathrm{~L}) \times 16(\mathrm{~h}) \mathrm{cm}$ water bath;

- heating element and temperature regulator for the bath setting;

- stirrer;

- perforated plate for probe positioning;

- 8 pt 100 temperature probes;

- calibration oil bath;

- standard temperature probe.

The technical specifications of the eight probes provided for the students were as follows (Fig. 2).

These eight probes did not undergo metrological confirmation (calibration and verification). Each pair of students was given a temperature probe and drew up an experimental plan validated by the instructor.

The device was designed in such a way that the temperature probes could be positioned at different points in 


\begin{tabular}{|c|c|}
\hline \multicolumn{2}{|c|}{ SPECIFICATIONS } \\
\hline Range & -50.0 to $150.0^{\circ} \mathrm{C} /-58.0$ to $302.0^{\circ} \mathrm{F}$ \\
\hline Resolution & $0.1^{\circ} \mathrm{C} / 0.1^{\circ} \mathrm{F}$ \\
\hline $\begin{array}{r}\text { Accuracy } \\
\pm 0.3^{\circ} \\
\pm 0 .\end{array}$ & $\begin{array}{l}{ }^{\circ} \mathrm{C}\left(-20 \text { to } 90^{\circ} \mathrm{C}\right) / \pm 0.5^{\circ} \mathrm{C} \text { (outside) } \\
5^{\circ} \mathrm{F}\left(-4 \text { to } 1942^{\circ} \mathrm{F}\right) / \pm 1^{\circ} \mathrm{F} \text { (outside) }\end{array}$ \\
\hline Probe & Stainless steel, $1 \mathrm{~m}$ (3.3') cable \\
\hline Environment & $\begin{array}{c}0 \text { to } 50^{\circ} \mathrm{C}\left(32 \text { to } 122^{\circ} \mathrm{F}\right) ; \\
\mathrm{RH} \max 95 \%\end{array}$ \\
\hline Battery Type & 1x1.5V AAA alkaline \\
\hline Battery Life & Approx. 3 years of use \\
\hline Dimensions & $106 \times 58 \times 19 \mathrm{~mm}\left(4.1 \times 5.2 \times 0.7^{\prime \prime}\right)$ \\
\hline Weight & $80 \mathrm{~g}(2.8 \mathrm{oz})$. \\
\hline
\end{tabular}

Fig. 2. Technical specifications of the probes used.

the bath and at different immersion depths. Special rubber bungs were used to ensure the stability of the probes (Fig. 3). The heterogeneity of the bath and the operating uncertainty of the different probes could thus be studied.

The equipment tested was a heated or cooled, temperature-regulated bath. The bath volume was around $25 \mathrm{~L}$ and the temperature setting was fixed at $37.0^{\circ} \mathrm{C}$.

The probe positioning plate provided made it possible to choose probe positions in accordance with the volume and technology of the bath (stirrer, heating element) so as to be able to observe the highest gradients.

The entire experiment was carried out at room temperature (around $23{ }^{\circ} \mathrm{C}$ ).

The first stage proposed consisted in listing the parameters influencing bath temperature measurement. In order to simplify the experimental plan, and for reasons of teaching time, it was hypothesized that the bath was perfectly stable. Likewise for any drift in the eight thermometers.

The main paremeters likely to be worth characterizing $[4,5]$ were as follows:

- deviation from setting;

- indication error;

- homogeneity;

- stability.

Some preliminary measurements at different immersion levels were used to determine the minimum probe depth to be respected. This was a depth of at least $20 \mathrm{~mm}$. All the tests were carried out at a probe immersion depth of $30 \mathrm{~mm}$.

The second stage consisted in estimating each standard uncertainty that might influence measurement. The regulated temperature setting of the bath was $37.0^{\circ} \mathrm{C}$. The resolution was $0.1{ }^{\circ} \mathrm{C}$. The probe was positioned on one of the sides of the water bath and completely immersed in the water. The measurement was stable over time to within the resolution.

In addition, a stirrer was placed near the heating element. The eight Pt 100 probes were positioned by choice using the perforated plate provided for the purpose. Each hole in the plate, which could take one probe,

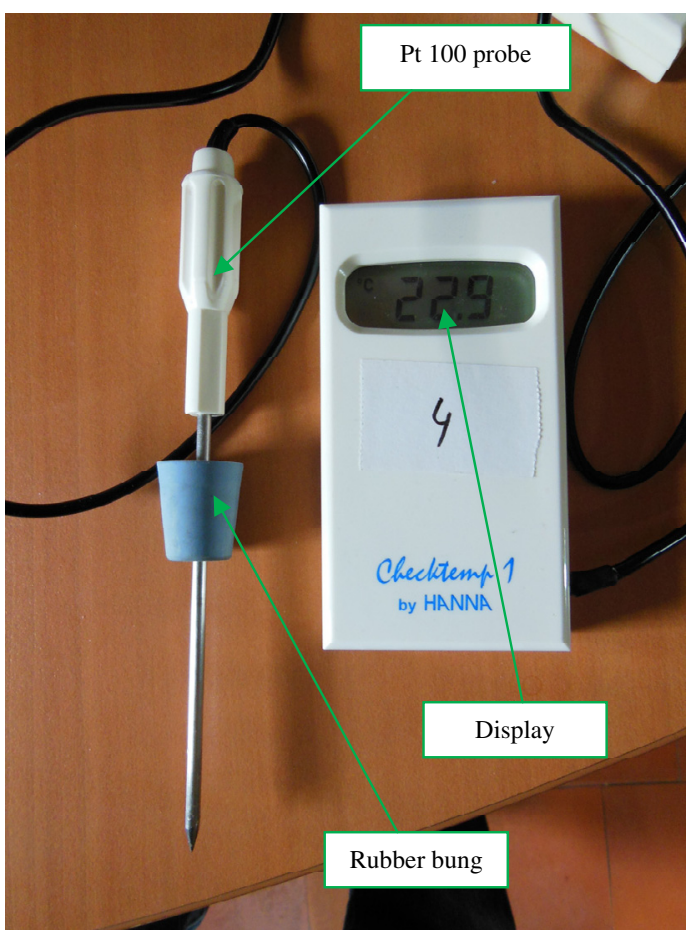

Fig. 3. Pt 100 probe used and positioning bung.

was coded: four rows (A to D) and ten columns (1 to 10). These different positions were used to take temperature measurements throughout the whole volume of the water bath so as to be able to map it.

An initial configuration was chosen (Fig. 4).

The probes were numbered 1 to 8 and were placed in given positions at an immersion depth of $30 \mathrm{~mm}$. The first results are presented in Figure 5.

These first results revealed an average difference of $-0.65{ }^{\circ} \mathrm{C}$ compared to the bath setting value.

In addition, the standard uncertainty corresponding to the homogeneity of the bath could be estimated $\left(u_{\text {homogeneity }}\right)$. The following figure was taken: maximum error of $0.6^{\circ} \mathrm{C}$ between the eight points of the bath at time $t$.

We used a type B method and chose a uniform distribution [6]: equivalent probability of being between a null deviation and the maximum deviation of $0.6{ }^{\circ} \mathrm{C}$ and null probability of being outside that range.

$$
\begin{aligned}
& u_{\text {homogeneity }}=\frac{\text { Deviation max }}{2 \sqrt{3}} \\
& u_{\text {homogeneity }}=\frac{0.6}{2 \sqrt{3}}=0.1732^{\circ} \mathrm{C} \text {. }
\end{aligned}
$$

The instructor compiled all the tests carried out by the students in a computer file already configured for the pupose, to process all the possible sources of uncertainty. This restitution of the tests undertaken by the students made it possible, in particular, to focus on the definition of some metrological terminology [1]. 


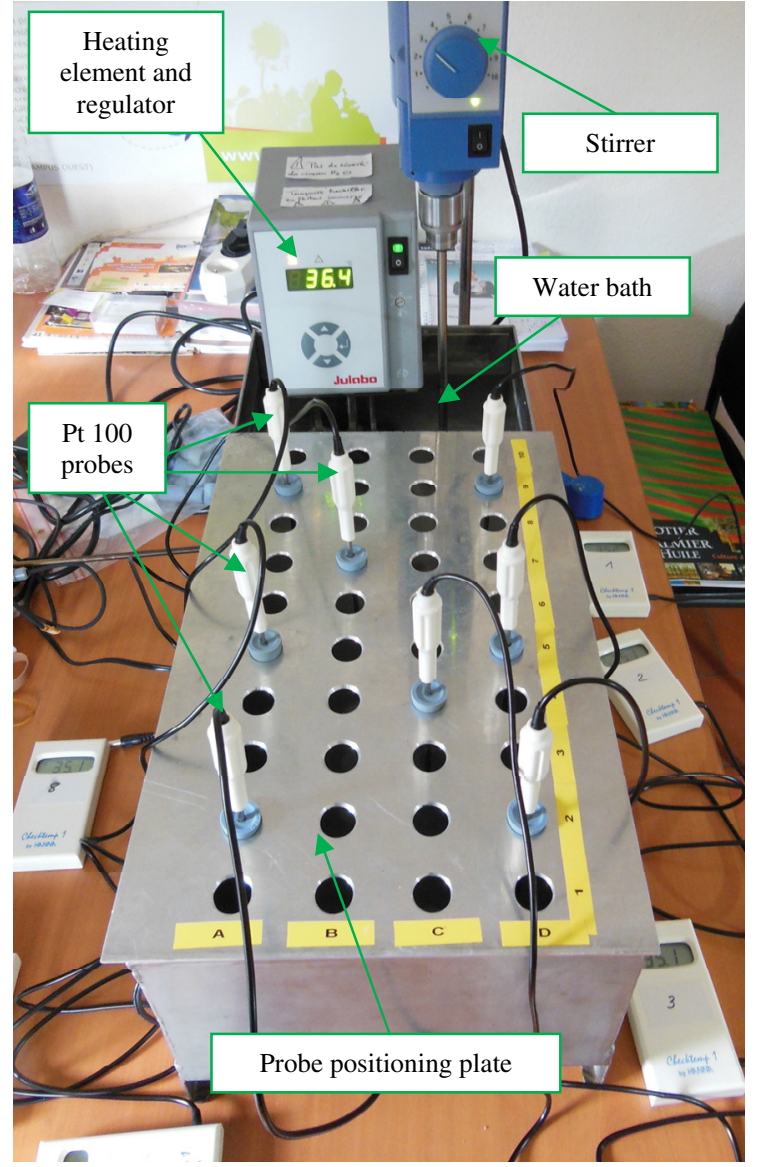

Fig. 4. Photo of the device (water bath and $8 \mathrm{Pt} 100$ temperature probes).

\begin{tabular}{|l|c|c|c|}
\hline Homogeneity (immersion depth $=\mathbf{3 0} \mathbf{~ m m}$ ) & $\begin{array}{c}\text { Probe } \\
\text { No. }\end{array}$ & $\begin{array}{c}\text { Grid } \\
\text { position }\end{array}$ & $\begin{array}{c}\text { Value } \\
\left({ }^{\circ} \mathrm{C}\right)\end{array}$ \\
\hline (8 different probes in 8 different positions): & 1 & D9 & 36.3 \\
\hline Consigne bain-maire $=37.0^{\circ} \mathrm{C}$ & 2 & D5 & 36.2 \\
Température local $=22.4^{\circ} \mathrm{C}$ & 3 & D2 & 36.3 \\
& 4 & A2 & 36.8 \\
& 5 & A5 & 36.2 \\
& 6 & A9 & 36.4 \\
& 7 & C4 & 36.4 \\
\hline Mean of the 8 values & 8 & B7 & 36.2 \\
Standard error of the 8 values & & & $\mathbf{3 6 . 3 5}$ \\
\end{tabular}

Fig. 5. Results of the 8 probes for a setting of $37.0^{\circ} \mathrm{C}$.

This file was also used to determine the type of uncertainty (A or B) and the type of propagation law involved (in this case it was a rectangular distibution $R$ ).

In addition, the resolution of the thermometers used by the students was $0.1^{\circ} \mathrm{C}$. The standard uncertainty arising from the resolution of the thermometers could therefore be evaluated ( $\left.u_{\text {resolution } \mathrm{TH}}\right)$.

A type $\mathrm{B}$ method and a uniform distribution was chosen: for example, for the temperature of $37.0^{\circ} \mathrm{C}$, the value could be between $36.95^{\circ} \mathrm{C}$ and $37.05^{\circ} \mathrm{C}$. We had an equivalent probability of being between these two values and

\begin{tabular}{|l|c|c|c|c|}
\hline $\begin{array}{l}\text { Probe error } \\
\text { (immersion depth }=\mathbf{3 0} \mathrm{mm} \text { ) } \\
\text { (reverse the 2 extreme value probes): }\end{array}$ & $\begin{array}{c}\text { Probe } \\
\text { No. }\end{array}$ & $\begin{array}{c}\text { Grid } \\
\text { position }\end{array}$ & $\begin{array}{c}\text { Value } \\
\left({ }^{\circ} \mathrm{C}\right)\end{array}$ & $\begin{array}{c}\text { Error } \\
\left({ }^{\circ} \mathrm{C}\right)\end{array}$ \\
\hline Water bath setting $=37.0^{\circ} \mathrm{C}$ & & & & \\
Local temperature $=24.4^{\circ} \mathrm{C}$ & 2 & A2 & 36.3 & -0.1 \\
& 4 & D5 & 36.7 & 0.1 \\
\hline
\end{tabular}

Fig. 6. Result of reversing the two probes with the largest temperature deviation.

there was no probability of being outside this range

$$
\begin{aligned}
& u_{\text {resolution } \mathrm{TH}}=\frac{\text { Resolution } \mathrm{TH}}{2 \sqrt{3}} \\
& u_{\text {resolution } \mathrm{TH}}=\frac{0.1}{2 \sqrt{3}}=0.02887^{\circ} \mathrm{C} .
\end{aligned}
$$

In addition, the standard uncertainty of measurement repeatability arising from a thermometer could be estimated ( $\left.u_{\text {Repeatability }}\right)$.

This standard uncertainty was assessed by a type A method. The measurement could be repeated around ten times and the experimental standard deviation measurered. Here, we adopted $S=0.03{ }^{\circ} \mathrm{C}$.

The measurement was carried out once therefore:

$$
u_{\text {repeatability }}=\frac{S}{\sqrt{n}}=\frac{0.03}{\sqrt{1}}=0.03^{\circ} \mathrm{C} \text {. }
$$

The accuracy of the thermometers was unknown. In fact, as the eight thermometers had not been calibrated beforehand, it was impossible to know their respective accuracy error. The instructor therefore emphasized the importance of the calibration certificate even though the probes were new.

In addition, the students were told to reverse the positions of the two probes giving the maximum temperature deviation (Fig. 5).

The results are shown in the table (Fig. 6).

This test made it possible to check that the deviation found came primarily from the thermometer and less from the probe position. It was therefore paramount to know the accuracy of each probe.

For that purpose, the students were provided with a calibration oil bath $\left(-30{ }^{\circ} \mathrm{C}\right.$ to $\left.125^{\circ} \mathrm{C}\right)$. A standard thermometer with a resolution of $0.001{ }^{\circ} \mathrm{C}$ was also available with its calibration certificate.

It was thus possible to calibrate the $\mathrm{Pt}$ 100 probes, [7,8], by placing the eight probes and the standard probe inside the oil bath (Fig. 7).

This calibration revealed the accuracy errors of each probe. The following table gives the calibration results (Fig. 8).

Calibration revealed a significant accuracy error for one of the eight probes. Indeed, the accuracy error for probe No. 4 was $+0.4{ }^{\circ} \mathrm{C}$. Without correction, the extent of the possible values was $\pm \mathrm{MTE}$ or $2 \mathrm{MTE}$. The MTE fixed for the eight thermometers was $\pm 0.6^{\circ} \mathrm{C}$. 


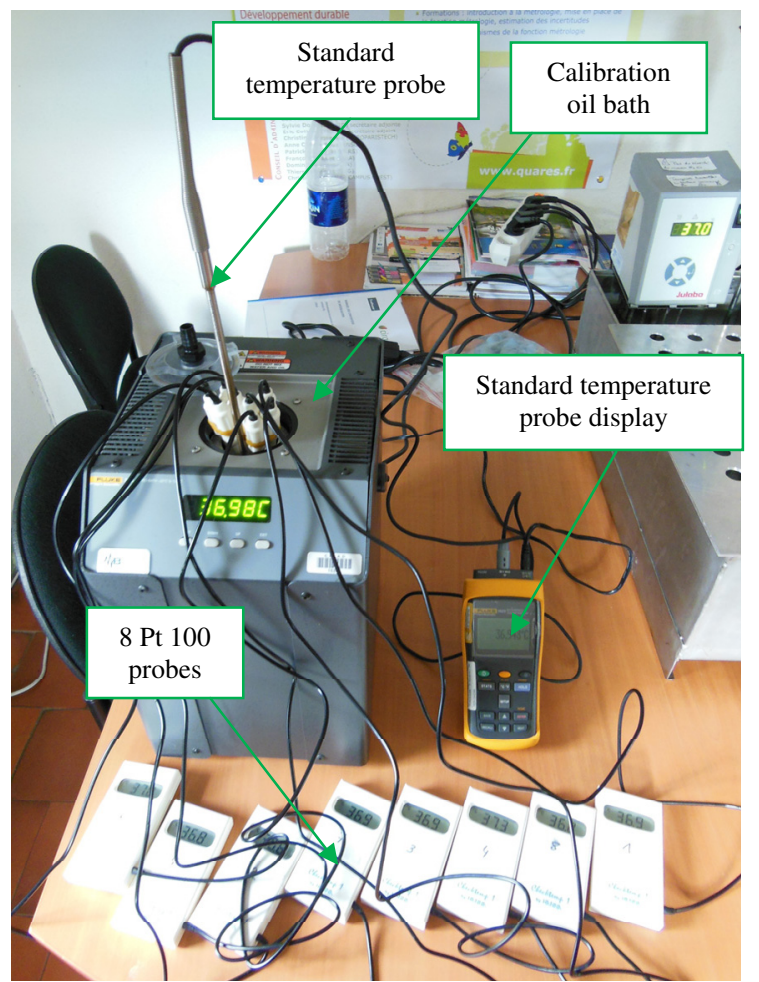

Fig. 7. Calibration oil bath dedicated to temperature probe verification (from $-30{ }^{\circ} \mathrm{C}$ to $125^{\circ} \mathrm{C}$ ).

\begin{tabular}{|c|c|c|c|c|c|c|c|}
\hline Calibration of the 8 probes & $\begin{array}{l}\text { Probe } \\
\text { No. }\end{array}$ & $\begin{array}{c}\text { Value( } \\
\left.{ }^{\circ} \mathrm{C}\right)\end{array}$ & $\begin{array}{l}\text { Value }\left({ }^{\circ} \mathrm{C}\right) \text { of } \\
\text { COFRAC } \\
\text { standard } \\
\text { thermometer }\end{array}$ & $\begin{array}{l}\text { Correction } \\
\text { (CE) in }{ }^{\circ} \mathrm{C}\end{array}$ & $\begin{array}{l}\text { Ue (CE) } \\
\text { in } \pm^{\circ} \mathrm{C}\end{array}$ & $\begin{array}{c}\text { Corrected } \\
\text { standard } \\
\text { value (CE) in } \\
{ }^{\circ} \mathrm{C}\end{array}$ & $\begin{array}{c}\text { Probe } \\
\text { correction } \\
\left({ }^{\circ} \mathrm{C}\right)\end{array}$ \\
\hline $\begin{array}{l}\text { Calibration oil bath setting = } \\
37.0^{\circ} \mathrm{C}\end{array}$ & 1 & 36.9 & \multirow{8}{*}{37.013} & \multirow{8}{*}{-0.010} & \multirow{8}{*}{0.050} & \multirow{8}{*}{37.003} & -0.103 \\
\hline \multirow[t]{7}{*}{ Local temperature $=24.8^{\circ} \mathrm{C}$} & 2 & 36.8 & & & & & -0.203 \\
\hline & 3 & 36.9 & & & & & -0.103 \\
\hline & 4 & 37.4 & & & & & -0.397 \\
\hline & 5 & 36.8 & & & & & -0.203 \\
\hline & 6 & 37.0 & & & & & -0.003 \\
\hline & 7 & 36.9 & & & & & -0.103 \\
\hline & 8 & 36.8 & & & & & 0.203 \\
\hline $\begin{array}{l}\text { Mean of the } 8 \text { values }\left({ }^{\circ} \mathrm{C}\right) \\
\text { Std error of the } 8 \text { values }\left({ }^{\circ} \mathrm{C}\right)\end{array}$ & & $\begin{array}{r}36.94 \\
0.20 \\
\end{array}$ & & & & & \\
\hline
\end{tabular}

Fig. 8. Calibration result for the Pt 100 probes.

In this case, we chose a type B method and a uniform distribution:

$$
\begin{aligned}
& u_{\text {accuracy ST }}=\frac{2 M T E}{2 \sqrt{3}}=\frac{M T E}{\sqrt{3}} \\
& u_{\text {accuracy ST }}=\frac{1.2}{\sqrt{3}}=0.6928{ }^{\circ} \mathrm{C} .
\end{aligned}
$$

These different uncertainty components could then be combined [6] to estimate the water bath temperature measurement uncertainty. The students were not asked to carry out this measurement but it was given to them so that they could see the order of magnitude of the measurement uncertainty. The calculation gave the following result:

\section{$u_{\text {measurement }}=$}

$\sqrt{u_{\text {Homogeneity }}^{2}+u_{\text {Resolution TH }}^{2}+u_{\text {Accuracy MT }}^{2}+u_{\text {Repeatability }}^{2}}$

\begin{tabular}{|l|c|c|}
\hline $\begin{array}{c}\text { Adjusted probe } \\
\text { values }\end{array}$ & $\begin{array}{c}\text { Probe } \\
\text { No. }\end{array}$ & $\begin{array}{c}\text { Value } \\
\left.{ }^{\circ} \mathrm{C}\right)\end{array}$ \\
\hline & 1 & 36.403 \\
& 2 & 36.403 \\
& 3 & 36.403 \\
& 4 & 36.403 \\
& 6 & 36.403 \\
& 7 & 36.503 \\
& 8 & 36.403 \\
\hline Mean of the 8 adjusted & \multicolumn{2}{|c|}{$\mathbf{3 6 . 4 2}$} \\
values $\left({ }^{\circ} \mathrm{C}\right)$
\end{tabular}

Fig. 9. Adjustment result for the eight probes.

$$
\begin{aligned}
& u_{\text {measurement }}=\sqrt{0.1732^{2}+0.02887^{2}+0.6928^{2}+0.03^{2}} \\
& u_{\text {measurement }}=0.715^{\circ} \mathrm{C} .
\end{aligned}
$$

Calibration uncertainty extended to $k=2$ was rounded off to two significant figures and revised up: $U_{\text {measurement }}=$ $\pm 1.5^{\circ} \mathrm{C}$.

For example, the expression of the result for probe No. 1 was as follows (for a water bath setting of $37.0^{\circ} \mathrm{C}$ ):

$$
T_{\text {measurement }}=(36.3 \pm 1.5)^{\circ} \mathrm{C} \quad(\text { at } k=2) .
$$

By studying the effect of the different uncertainty sources on this measurement, it was found that accuracy was the preponderant factor of the overall bath temperature uncertainty. It was therefore paramount to integrate the accuracy error of the probes after their calibration.

It was henceforth possible to adjust the probes in line with the accuracy errors found. The mean of the eight adjusted probes was calculated and the results are shown (Fig. 9).

The mean of the eight adjusted values for the eight probes was used to determine the mean deviation from the temperature setting value. The deviation was $-0.58{ }^{\circ} \mathrm{C}$. This result made it possible to adjust the bath setting value. The adjustment recentred the setting value on the target value of $37.0^{\circ} \mathrm{C}$. Thanks to this calibration, the new bath setting value could therefore be fixed at $37.6{ }^{\circ} \mathrm{C}$.

After stabilization of the bath at the setting of $37.6^{\circ} \mathrm{C}$ and adjustment of the Pt 100 probes, the extended overall uncertainty of the temperature measurement was reduced from $U= \pm 1.5{ }^{\circ} \mathrm{C}($ at $k=2)$ to $U= \pm 0.36{ }^{\circ} \mathrm{C}($ at $k=2)$.

For example, the expression of the result for probe No. 1 could now be as follows:

$$
T_{\text {measurement }}=(37.0 \pm 0.4){ }^{\circ} \mathrm{C} \quad(\text { at } k=2) .
$$

It was thus possible to divide measurement uncertainty by at least a factor of 3 .

\section{Conclusion and prospects}

These two workshops thus made it possible to explain the metrology approach required to master measurements and thereby the ensuing results. The teaching scenario adopted placed the students in a situation where they put into 
practice the theoretical notions previously taught. The purpose of this practical work was to make the students aware of certain concepts such as repeatability, accuracy and capability of an instrument.

A more complete module would enable trainees to also process their data using a predefined standard file.

The creation of this training module was coherent with the organization's remit to train through research and for research in countries of the South. The use of instruments and quantities widely used in diverse contexts in the South means that it is suitable for and transferrable to developing countries.

\section{References}

1. VIM 3, Vocabulaire international de métrologie (JCGM $200: 2008$, VIM $3^{\text {e }}$ édition 2008)
2. ISO 14253-1, Partie 1: Règles de décision pour prouver la conformité ou la non-conformité à la spécification (2013)

3. NF EN 45501, Aspects métrologiques des instruments de pesage à fonctionnement non automatique (1993)

4. LAB GTA 24, Guide technique d'accréditation pour la caractérisation et la vérification des enceintes thermostatiques et climatiques, fours et bains thermostatés (2009)

5. LAB GTA 08, Guide technique d'accréditation en température (2011)

6. NF ENV 13005, Guide pour l'expression de l'incertitude de mesure (1999)

7. FD X 07-028 Métrologie : Procédure d'étalonnage et de vérification des thermomètres, Estimation des incertitudes sur les mesures de température (2002)

8. NF X 15-140, Mesure de l'humidité de l'air, Enceintes climatiques et thermostatiques, Caractérisation et vérification 